\title{
Challenges and Opportunities in implementing leachate recirculation in Indonesia: technical aspects
}

\author{
Wiharyanto Oktiawan ${ }^{I}$, Ika Bagus Priyambada $^{I}$, Purwono Purwono ${ }^{2 *}$ \\ ${ }^{1}$ Department of Environmental Engineering, Faculty of Engineering, Diponegoro University, 50275 \\ Semarang Indonesia \\ ${ }^{2}$ Center for Science and Technology, IAIN Surakarta, 57168 Kartasura, Indonesia
}

\begin{abstract}
Sanitary landfill is the most commonly used way to process municipal solid waste (MSW) in most countries including Indonesia. Sanitary landfill system produces leachate which contains a lot of inorganic pollutants, heavy metals, dissolved organic matter, and xenobiotics. Most leachate treatment plants in Indonesia consist of stabilization ponds, aeration ponds, anaerobic ponds, maturation ponds, and tertiary treatment such as wetlands. A small part of waste water treatment plant (WWTP) consists of equalization tanks, facultative bodies, aeration tanks, polishing pools, sedimentation tanks, chemical and biological processing tanks, mud ponds and sand filters. In fact, leachate was found at depths of $4,9,15,20,30 \mathrm{~m}$ in final processing site in the Gampong Jawa, Banda Aceh. Real conditions, some WWTPs do not function properly, buildings are damaged, and effluent quality exceeds the standard. Leachate needs to be managed properly, so as not to cause pollution to ground water and surface water. Although, there are many negative problems related to leachate management, but there are many opportunities that can be developed. These opportunities not only reduce their negative impacts but also help meet energy needs and improve environmental health in the long run. This review article aims to discuss the opportunities and challenges of leachate recirculation in Indonesia in terms of technical aspects.
\end{abstract}

\section{Introduction}

The rate of population increase, economic growth, urbanization, and rapid industrialization lead to an increase in waste generation, volume, type, and increasingly diverse characteristics of waste [1]. Around 5\% of the total amount of waste can be processed by the community, the remaining $95 \%$ is taken to the final processing site (TPA), while the landfill is very limited [2]. In most countries, sanitary landfill is currently the most commonly applied way to treat urban solid waste (MSW) [3]. The volume of waste is very large and high rainfall produces leachate in large quantities as well. As an example The

\footnotetext{
* Corresponding author: purwono.ga@gmail.com
} 
Jatibarang TPA, which is a final waste treatment facility in the city of Semarang, manages 4,000 tons of waste every day with a composition of $61.95 \%$ organic waste from the total municipal waste (MSW) produced [4]. The existing processing unit has not produced effluent quality in accordance with quality standards. Visually, the color of water in the inlet channel is not much different from the outlet[5]. Leachate from landfill needs to be managed properly so as not to cause pollution to ground water, surface water, and the environment.

Design of TPA Banyuroto, Kulon Progo Regency consists of from the initial storage pond, facultative pond and pond outlet with the addition of water hyacinth plants [6]. Supit Urang IPAL Pool, Malang uses 3 pools, namely stabilization ponds, aeration ponds and maturation ponds [7]. The Bantar Gebang Integrated Waste Management Facility (TPST) in 2018 uses an equalization tub, facultative tub, aeration tub, polishing pool, sedimentation tub, chemical and biological treatment tub, mud pond and sand filter [8]. Leachate treatment system applied by Cipayung Landfill in Depok City, West Java is using a stabilization pool consisting of anaerobic ponds, facultative pools, and maturation / maturation ponds[9]. Based on the results of surveys and measurements in the field, analysis and evaluation of data obtained from Sarimin's research results[10], TPA Putri Cempo has an inadequate and unusable Waste Water Treatment Plant (WWTP), the condition of the wastewater treatment plant that has been damaged and the location of the WWTP far from the Active dump. Fitria et al.[11] found landfill leachate found at depths of 4, 9, 15, 20, $30 \mathrm{~m}$ in Java Village Landfill Banda Aceh.Leachate treatment system is made with the aim of reducing pollutants in the leachate, without using equipment that requires high investment and complicated maintenance.

Recirculation is Leachate treatment alternatives are interesting because they are effective for improving the quality of leachate [12]. This is not only an option for inexpensive leachate removal, but at the same time accelerating the waste stabilization process[13]. Leachate recirculation method saves off-site disposal costs, increases methane gas production, and increases the use of clear added value for people who use methane[14]. Comparative to the development of leachate treatment technology in recent years, recirculation of leachate treatment is a good prospect to be applied in Indonesia.

\section{Leachate}

Leachate produced from landfill can be evaluated from qualitative and quantitative aspects. Production leachate is highly influenced by external or internal factors. While these internal factors can be ignored, while external factors include meteorological variations, local hydrological variations, and waste characteristics. Leachate quality depends on rainfall, composition of solid waste, and age [8].

According to Bove et al. [15] leachate from a young landfill (less than one year old) produces a leachate that is neutral or even acidic. The anaerobic process of organic component degradation is likely to have reached the acidogenic phase. Older landfill, that is, more than five years old, is alkaline with a $\mathrm{pH}>8$. The ratio of Biological Oxygen Demand (BOD) to Chemical Oxygen Demand (COD) decreases with increasing TPA life due to the release and degradation of waste biopolymers[16]. In detail, leachate formation consists of three main processes, namely hydrolysis, aerobic degradation (phase 1), and anaerobic degradation (phase 2-4). Hydrolysis is carried out by aerobic bacteria that decompose polysaccharides into monosaccharides, lipids become fatty acids and glycerol, whereas proteins become amino acids[16, 17]. Aerobic degradation changes organic pollutants to $\mathrm{CO}_{2}, \mathrm{H}_{2} \mathrm{O}$, nitrate and sulfate with very short duration, because oxygen is consumed completely within a few days. Anaerobic degradation consists of acid fermentation which causes a decrease in $\mathrm{pH}$ to 5.5-5.6, due to the formation of $\mathrm{CO} 2$ and 
volatile fatty acids [16]. The next stage begins with the slow growth of methanogenic bacteria, then the transformation of $\mathrm{CO}_{2}$ and volatile acids into methane. Methane production continues until all biodegradable organic matter decomposes. The whole process takes up to $15-20$ years $[15,17]$.

\section{Existing leachate treatment}

Based on real conditions in Indonesia, most leachate WWTPs use biological treatment, both aerobic processes, anaerobic processes, or a combination of both [4, 6 - 11]. Biological processing was chosen because of its simplicity, low maintenance costs, and fast start-up [16]. There is one Integrated Waste Management Site that applies physical-chemical treatment, namely Bantar Gebang. In 2018, Bantar Gebang used an equalization tub, facultative tub, aeration tub, polishing pond, settling tub, chemical and biological treatment tank, mud pond and sand filter [8]. Biological treatment cannot reduce heavy metals in waste and allow the formation of scum. Biological microorganisms play an important role in degrading organic pollutants. Biological processes are quite effective in treating wastes containing high BOD values. Aerobic process is very effective to degrade organic pollutants and nitrogen compounds (nitrification / denitrification) contained in leachate originating from young landfill with a BOD / COD ratio> 0.5 [18]. Conversely, low BOD / COD ratios such as those found in old leachate require special treatment to reduce nitrogen pollutants. Aerobic treatment such as lagoons has a typical depth of about 1-2 $\mathrm{m}$ and aeration systems such as aerators, jet aerators, or compressed air spreaders.

Anerobic leachate treatment does not produce much mud. However, under stationary conditions, this system requires partial effluent recirculation[3]. The effectiveness of anaerobic systems is strongly influenced by microbial and operational factors including $\mathrm{pH}$, temperature, HRT, COD, and BOD. Methanogenic bacteria are very sensitive to acidity. Anaerobic treatment produces gas that can be used as boiler heating $[15,16]$. The effluent from the anaerobic process causes odor due to the large number of ammonia compounds, hydrogen sulfide, and other volatile compounds. The main advantage of the anaerobic process is that COD and BOD allowances are quite effective and HRT is short[16, 19].

\section{Opportunities}

Recirculation leachate has the potential to protect the environment in the long run. Recirculation is an attractive processing alternative because it can improve quality and reduce the amount leachate. According to Abbas et al. [12], the concept of leachate recirculation is a fairly effective method for treating leachate. Recently, Indonesia has innovated waste management by building a waste electric power plant. The construction of it will begin in four regions namely Surabaya, Bekasi, Solo and DKI Jakarta [20]. It construction is a good effort to reduce the amount of waste available to use it in other forms. However, the landfill leachate management system has not shown encouraging progress. Implementing a leachate recirculation system is not only an inexpensive choice in reducing maintenance costs, but can also accelerate the process of stabilizing waste [13]. Leachate recirculation increases methane gas production in landfills. According to Cossu \& Raga[17], overall biological processes that occur in landfill (stage hydrolysis, aerobic degradation, anaerobic degradation) can last up to 15-20 years. This will increase added value for methane gas users such as households. Leachate recirculation is not only applied in the active zone but can also be applied in the passive zone. The number of leachate recirculated can reach half a million gallons / hour [14]. 


\section{Challenge}

Leachate recirculation is incapable reduce the volume of waste produced by the community. Need to assess other technologies that are most appropriate in reducing the volume of waste. Leachate distribution in landfills is uneven (figure 1 (a)). The ideal leachate distribution is illustrated in Figure 1 (b). This situation causes the recirculation process cannot reach all parts of the waste.

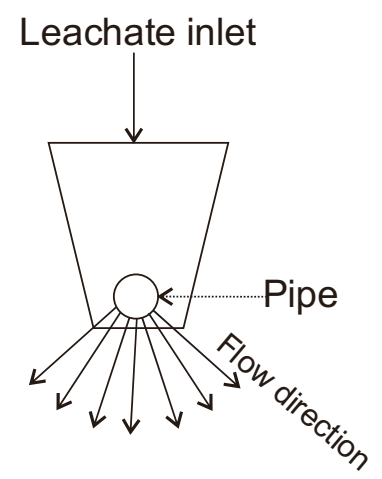

(a)

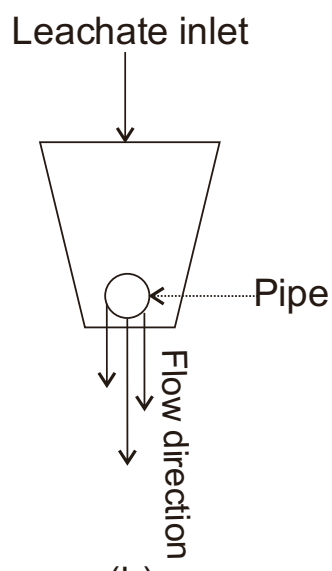

(b)

Figure 1. Scheme of leachate distribution when waste is distributed unevenly (a), evenly distributed leachate (b)

Waste decomposition process produces unpleasant odors such as $\mathrm{H} 2 \mathrm{~S}, \mathrm{NH} 3$, and other volatile compounds. In addition, most landfills in Indonesia use the sanitary landfill system. This system is done by removing and piling up garbage in concave locations, compacting it, and then filling it with soil. This condition causes the leachate to seep into the soil. Leachate construction is largely spread to all sides of the landfill, making it difficult to collect leachate. Landfill locations in dry areas (annual rainfall $200 \mathrm{~mm}$ ) cause ammonium levels to increase. This causes inhibited anaerobic degradation, which results in a decrease in the amount of methane gas and an increase in COD concentrations [21]. Annual rainfall in Indonesia ranges from 500-3,000 mm [22]. Biogas production with a high methane content $>70 \%$ on the one hand is a significant advantage from an energy perspective, but on the other hand requires the adoption of appropriate safety measures to prevent the formation of explosive methane and oxygen blends [23, 24]. The amount of gas will decrease with increasing age of the landfill. Leachate composition is dominated by recalcitrant compounds which are non-biodegradable, making it difficult to process biologically [12]. If done recontinues circulation, eventually the waste will be saturated. At this condition, leachate recirculation is not able to increase methane gas production [14].

\section{Conclusion}

Leachate recirculation has the potential to protect the environment in the long time. This system can be applied in new and old landfills in Indonesia. The quality of the leachate is getting better, the heavy metal component in the leachate does not pollute water bodies, nor ground water. The whole biological process can produce methane gas which can last up to 15-20 years. This will increase added value for methane gas users such as households. Biogas production with a high methane conten $>70 \%$ requires a good infrastructure and 
management system to prevent explosive events. Landfill conditions in Indonesia are mostly without liners. This reduces the effectiveness of the recirculation process.

\section{References}

1. V. Srivastava, S. A. Ismail, P. Singh, and R. P. Singh. Environ. Sci. Biotechnol. 14 (2015).

2. P. Purwaningrum, Indones. J. Urban Environ. Technol., 8 (2016)

3. S. Renou, J. G. Givaudan, S. Poulain, F. Dirassouyan, and P. Moulin, J. Hazard. Mater., 150 (2008).

4. W. Oktiawan, I. Wisnu Wardhana, E. Sutrisno, D. Gorat, and A. Rizky Rizaldianto, E3S Web Conf., 125 (2019)

5. A. Rezagama, M. Hadiwidodo, P. Purwono, N. F. Ramadhani, and M. Yustika, Teknik, 37 (2016)

6. R. A. Thomas and D. H. Santoso, J. Sci. Tech, 5 (2019)

7. R. A. Prayoga, University of Muhammadiyah Malang, (2018)

8. I. Fadhilah and L. Fitria, J. Nas. Kesehat. Lingkung. Glob. 1 (2020)

9. M. Handono, Institut Pertanian Bogor, (2010)

10. S. Sarimin, Universitas Pembangunan Nasional Veteran Yogyakarta, (2019).

11. B. Fitria, I. Maharani, Lukmannul, and D. Sugiyanto, J. Aceh Phys. Soc., 7 (2018)

12. Abbas et al., Am. J. Appl. Sci. 6 (2009).

13. Y. Li, L. Wang, and S. Zheng, Journal Wuhan University of Technology. 23 (2008)

14. A. Karidis, "Is Landfill Recirculation Advisable?," Waste 360, (2018).

15. D. Bove, S. Merello, D. Frumento, S. Al Arni, B. Aliakbarian, and A. Converti, Chem. Eng. Technol., 38 (2015)

16. G. Tchobanoglous and F. Kreith, Handbook of Solid Waste Management Second Edition, Second. (2002)

17. R. Cossu and R. Raga. Waste Manag. 28 (2008)

18. J. M. Lema, R. Mendez, and R. Blazquez, Water. Air. Soil Pollut. 40 (1988)

19. D. D. Focht and A. C. Chang, Adv. Appl. Microbiol., 19 (1975)

20. I. Ihsanuddin, Kompas, (2019)

21. O. Chamem, J. Fellner, and M. Zairi, Waste Manag. Res., (to be publish)

22. E. Pranita, Kompas, (2019)

23. A. Bonmatí and X. Flotats. Waste Manag., 23 (2003)

24. L. Liu, H. Xiong, J. Ma, S. Ge, X. Yu, and G. Zeng, 2018 (2018) 